\title{
Oceanography
}

CITATION

Kappel, E.S. 2015. Quarterdeck: Pursuing Earth and ocean sciences priorities as one community. Oceanography 28(2):5-6, http://dx.doi.org/10.5670/oceanog.2015.47.

DOI

http://dx.doi.org/10.5670/oceanog.2015.47

COPYRIGHT

This article has been published in Oceanography, Volume 28, Number 2, a quarterly journal of The Oceanography Society. Copyright 2015 by The Oceanography Society. All rights reserved.

USAGE

Permission is granted to copy this article for use in teaching and research. Republication, systematic reproduction, or collective redistribution of any portion of this article by photocopy machine, reposting, or other means is permitted only with the approval of The Oceanography Society. Send all correspondence to: info@tos.org or The Oceanography Society, PO Box 1931, Rockville, MD 20849-1931, USA. 


\section{Pursuing Earth and Ocean Sciences Priorities As One Community}

rom May 4-6, 2015, I had the privilege of attending the "Workshop on Future Seismic and Geodetic Facility Needs in the Geosciences" in Leesburg, Virginia. Roughly 100 scientists from the largely land-based US seismic and geodetic communities gathered to formulate the key scientific research questions that they will be pursuing beyond 2018, and to develop recommendations regarding the "foundational" and "frontier" facilities required to conduct the science (for more information, see http://www.iris.edu/ hq/workshops/2015/05/future_seismic and_geodetic_facility_needs_in_the geosciences). The workshop took place in the context of the National Science Foundation's Division of Earth Sciences' need for community input as it plans to recompete management and operations of its seismic and geodetic facilities in 2016 (see http://www.nsf.gov/pubs/2015/nsf15076/ nsf15076.jsp). Those facilities include the Incorporated Research Institutions for Seismology (IRIS; http://www.iris.edu), UNAVCO (https://www.unavco.org), and EarthScope (http://www.earthscope.org), which is managed jointly by IRIS and UNAVCO.

From the outset of the May workshop, it was clear that many in the seismic and geodetic communities believe that pursuing their scientific priorities requires an extension of land operations into the ocean. Recommendations include deploying arrays of ocean bottom seismometers for passive and active seismic experiments, installing seafloor geodetic instruments to measure horizontal and vertical motion of the seafloor, and establishing several longterm broadband seismic stations to extend global seismic coverage into the ocean. Workshop participants also discussed the need to add sensors-such as those that continuously record bottom pressure and temperature-to ocean floor seismic and geodetic instruments. The concept of deploying permanent ocean bottom seismographs to complete uniform global coverage of the Global Seismographic Network (http://www.iris.edu/hq/programs/gsn) dates back to the 1990s (e.g., Stephen et al., 2003). These stations have become more feasible thanks to technological advances that include autonomous underwater vehicles that could download and transmit the data from remote sites, and improved battery lifetimes and very precise atomic clocks that enable multiyear deployments. Workshop participants also mentioned the need for improved marine magnetotelluric and controlled source electromagnetic capabilities and for high-resolution bathymetry to enable more precise knowledge of site characteristics for input into crustal models.

These foundational and frontier facilities would support studies of subjects ranging from subduction zone systems beyond Cascadia (e.g., see Toomey et al., 2014), deep mantle structure (slabs and plumes), magmatic systems (mid-ocean ridges, underplating), and also "water" (e.g., cryosphere, sea level, and fault zone properties). Not surprisingly, these topics are similar to several decadal science priorities, such as sea level change, the formation and evolution of ocean basins, and the character of the subseafloor environment, set forth in the just-released report of the NRC Committee on Guidance for NSF on National Ocean Research Priorities: Decadal Survey of Ocean Sciences (NRC, 2015, see Table 3-2 summary). The NRC report also lists geohazards (earthquakes, volcanoes, landslides, tsunamis) as a priority. While discussion of geohazards research at the recent "Futures" workshop was vigorous and was seen as important, the participants remained focused on land-based studies.

The Futures writing committee is now crafting the workshop report, which will articulate the outcomes of the meeting discussions and describe in more detail the seismic and geodetic communities' scientific priorities and infrastructure needs. The report will be made available for community input in mid-to-late June for one month on the meeting website. I strongly encourage members of the ocean sciences community to review this draft and provide comments to the writing committee. The TOS website will provide a link to the workshop draft.

In this age of multidisciplinary, interdisciplinary, and transdisciplinary research, the overlap in science priorities for Earth and ocean sciences articulated by the two groups is not at all surprising. The 2015 NRC report and the Futures workshop report (final to be released in 


\title{
The Oceanography Society Fellows Program
}

\author{
http://www.tos.org/awards_honors/fellows_program.html
}

\author{
Recognizing Individuals Who Have Attained Eminence in
}

Oceanography Through Their Outstanding Contributions to

the Field of Oceanography or Its Applications

\section{CALL FOR NOMINATIONS}

The Oceanography Society (TOS) Fellows Program has been established to recognize individuals who have attained eminence in oceanography though their outstanding contributions to the field of oceanography or its applications during a substantial period of years. TOS members are encouraged to participate in honoring such individuals by nominating or seconding their election as a TOS Fellow. TOS members from all areas of oceanography will be considered for the Fellows Program. A recommendation for advancement to TOS Fellow is appropriate after an individual has been a TOS member for at least three years, depending on his or her contributions to the field.

The main criteria for being elected a TOS Fellow are outstanding and sustained contributions, and devotion to the broad field of oceanography, commensurate with the founding principles of the Society.

A complete nomination package includes:

- A three-page (maximum) nominating letter

- Three to five supporting letters, each two pages or less in length

- A document outlining the candidate's professional history

To be considered this year, a complete nomination package must be submitted electronically to info@tos.org (subject: Chair, Fellows Committee) by October 31, 2015. Important details and instructions regarding the nomination process are provided at http://www.tos.org/ awards_honors/fellows_program.html. This information is also available upon request from the TOS Executive Director (info@tos.org).

\section{Visit the new TOS Jobs Center}

Providing services for both employers and jobseekers.

\section{REFERENCES}

National Research Council. 2015. Sea Change: 2015-2025 Decadal Survey of Ocean Sciences. Committee on Guidance for NSF on National Ocean Science Research Priorities: Decadal Survey of Ocean Sciences, Ocean Studies Board, Division on Earth and Life Studies, National Research Council, National Academies Press, Washington, DC, 120 pp., http://www.nap.edu/catalog/21655/ sea-change-2015-2025-decadal-survey-of-oceansciences.

Stephen, R.A., F.N. Spiess, J.A. Collins, J.A. Hildebrand, J.A. Orcutt, K.R. Peal, F.L. Vernon, and F.B. Wooding. 2003. Ocean Seismic Network Pilot Experiment. Geochemistry, Geophysics, Geosystems 4(10), http://dx.doi.org/ 10.1029/2002GC000485.

Toomey, D.R., R.M. Allen, A.H. Barclay, S.W. Bell, P.D. Bromirski, R.L. Carlson, X. Chen, J.A. Collins, R.P. Dziak, B. Evers, and others. 2014. The Cascadia Initiative: A sea change in seismological studies of subduction zones. Oceanography 27(2):138-150, http://dx.doi.org/10.5670/oceanog.2014.49.

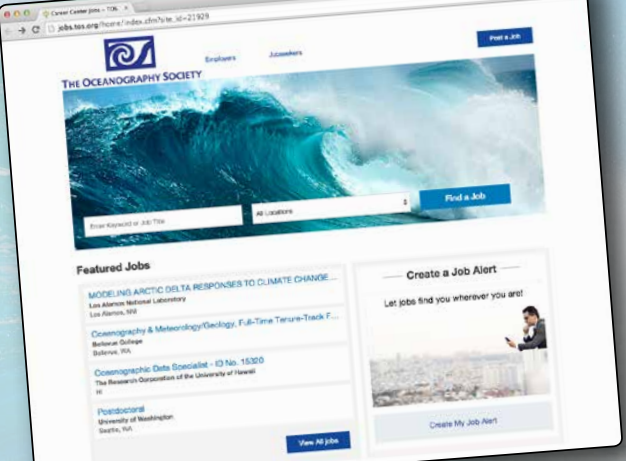

